\title{
Pemanfaatan Rumput Sebagai Kompos Untuk Kesuburan Tanah Bekas Tambang Batu Dengan Uji Bibit Tanaman Kakao (Theobroma cacao L.)
}

\author{
Rossy Mirasari* \\ Program Studi Pengelolaan Perkebunan, Politeknik Pertanian Negeri Samarinda, Samarinda 75242 \\ rossymalik678@gmail.com \\ *Corresponding author
}

\begin{abstract}
Abstrak - Artikel ini membahas tentang penelitian pemanfaatan rumput sebagai kompos untuk kesuburan tanah bekas galian batu dengan uji tanaman kakao (Theobroma Cacao L.). Tujuan penelitian ini adalah untuk mengetahui kandungan unsur hara pada kompos yang dibuat, melakukan pengomposan yang berkualitas dan dapat memperbaiki kesuburan tanah bekas galian dengan uji tanaman kakao. Kompos yang terbuat dari bahan rumput cincang kemudian ditambahkan dengan aktivator EM4. Bahan kompos dimasukkan ke dalam karung goni kemudian diikat dan bagian bawahnya diberi lubang untuk mengalirkan air. Selama proses pembuatan kompos, karung goni diletakkan di atas alas kering dan diberi naungan untuk menghindari sinar matahari dan air hujan. Proses pembuatan kompos selama 14 hari. Kompos dikatakan matang jika warna kompos hitam, aroma seperti aroma tanah, tekstur remah, suhu normal (sama dengan suhu kamar), dan nilai $\mathrm{C} / \mathrm{N}$ ratio sekitar 20 - 30. Hasil penelitian menunjukkan bahwa kompos yang dihasilkan berkualitas baik, dilihat dari hasil analisis kimia menunjukkan kandungan $\mathrm{C} / \mathrm{N}$ kompos 7,6, $\mathrm{pH}$ $\left(\mathrm{H}_{2} \mathrm{O}\right) 6,86, \mathrm{pH}(\mathrm{KCl}) 6,78$ dan kandungan unsur hara lengkap mikro. dan makro. Sedangkan tanah bekas galian batu yang diberi perlakuan kompos juga menunjukkan hasil analisis kimiawi yang baik. Terbukti, kompos dapat memperbaiki kesuburan tanah bekas galian. Parameter tanaman menunjukkan hasil nyata yang berbeda pada semua parameter tinggi baik tanaman, jumlah daun, diameter batang (umur 2, 4, 6, 8 minggu setelah pindah ke tanaman) dan luas daun pada akhir pengamatan menunjukkan perlakuan batu. Tanah gali dengan penambahan kompos lebih baik dibandingkan tanah gali batu murni tanpa perlakuan.
\end{abstract}

Kata kunci - rumput, kompos, tanah bekas tambang batu

\section{PENDAHULUAN}

Umumnya masyarakat kita setelah memotong rumput di pekarangan rumah atau perkantoran langsung ditimbun dan dibakar, terkadang dibuang begitu saja. Padahal rumput dapat dimanfaatkan sebagai kompos sehingga dapat mengurangi pencemaran lingkungan akibat limbah rumput yang dibuang dan tumbuh liar dimana-mana sehingga menimbulkan masalah lingkungan seperti bau, gas beracun, hama, penyakit dan pemandangan yang tidak enak dipandang.

Dengan menggunakan activator seperti EM4, rumput dapat diolah menjadi kompos dengan cepat serta kompos yang dihasilkan berkualitas. Dimana EM4, merupakan activator yang dapat mempercepat dekomposisi rumput sehingga kompos cepat terurai (cepat jadi), tidak menimbulkan bau dan masalah-masalah lingkungan dan kesehatan dapat teratasi. Selain itu EM4, juga akan menambah kandungan unsur hara dalam kompos itu sendiri sehingga dihasilkan kompos yang memiliki kandungan unsur hara lengkap baik makro maupun mikro.

Di daerah Sempaja khususnya, banyak kita jumpai lahan-lahan galian batu (tambang batu). Setelah diadakan penggalian, lahan dibiarkan begitu saja sehingga membentuk gubangan-gubangan. Dampak yang di timbulkannya adalah lahan menjadi mudah tererosi dan miskin unsur hara bahkan unsur hara hilang karena sudah mengalami proses pembalikan tanah. Tanaman tidak akan dapat tumbuh di lahan bekas galian tersebut sehingga terbentuk hamparan-hamparan lahan kosong yang gersang. Dan dampak yang paling nyata yang terjadi beberapa tahun terakhir ini adalah terjadinya banjir apabila musim hujan tiba yang diakibatkan lahan bekas galian itu kosong (tanpa tanaman/tumbuhan) yang mampu menahan air hujan. Sangat disayangkan keadaan seperti itu.

Apabila lahan-lahan tersebut ditambahkan unsur hara dengan memanfaatkan rumput sebagai kompos tentu hasilnya akan jauh berbeda, tanaman dapat tumbuh dengan baik dan mampu menahan, menyerap dan menyimpan air hujan sehingga resiko banjir dapat dikurangi. Penambahan kompos dari rumput ke lahan bekas galian dapat menambah kandungan unsur hara dalam tanah, memperbaiki sifat fisik, kimia dan biologi tanah. Penambahan kompos dari rumput merupakan solusi yang paling tepat. Di mana disatu sisi mengatasi limbah rumput dan dilain sisi dapat memperbaiki sifat fisik, kimia dan biologi lahan bekas galian. 
Tanaman yang diujikan adalah tanaman kakao, dimana tanaman kakao ini merupakan salah satu tanaman tahunan andalan perkebunan dan banyak terdapat di Samarinda. Tanaman kakao dapat tumbuh pada tanah yang memiliki kisaran $\mathrm{pH} 4,0-8,5$. Sedangkan pada lahan bekas galian $\mathrm{pH}$ tanahnya asam berkisar $<5$, sehingga diharapkan tanaman kakao ini dapat tumbuh dengan baik di lahan tersebut.

Berdasarkan hasil penelitian ini diharapkan dapat memberikan informasi kepada petani dan pemerhati pertanian bahwa rumput dapat dimanfaatkan sebagai kompos yang dapat memberikan kesuburan atau memperbaiki kesuburan pada tanah yang miskin unsur hara sekalipun seperti tanah bekas galian batu, dengan cara tanah galian batu diberi kompos dan diuji dengan menggunakan tanaman kakao.

\section{METODOLOGI}

\section{A. Tempat dan Waktu Penelitian}

Penelitian ini dilaksanakan selama 4 (empat) bulan, 20 Juli sampai dengan 15 November 2015, meliputi persiapan, pembuatan kompos, penanaman, pengumpulan data, analisa kompos, pengolahan data dan penulisan laporan.

Lokasi penelitian bertempat di Perumahan Solong Durian Blok C3 No.10 Sempaja Samarinda, dan analisa media tanam dilakukan di laboratorium Ilmu tanah Manajemen Pengelolaan Hutan Politeknik Pertanian Negeri Samarinda.

\section{B. Alat dan Bahan}

Bahan yang digunakan adalah : rumput, EM4, gula pasir, air tanah, tanah galian batu, bibit tanaman kakao, fungisida, pestisida, polybag, kayu pembuat rumah plastik, plastik, paku, label penelitian, bahan analisis kimia kompos dan bahan analisis kimia tanah.

Alat yang digunakan adalah : alat tulis-menulis, meteran, penggaris, cangkul, skop, mikrokalifer, gembor, sprayer, arco, timbangan, karung goni, alat analisis kimia kompos dan alat analisis kimia tanah.

\section{Metode Penelitian}

Dalam penelitian ini digunakan pengumpulan data primer dan sekunder dengan cara sebagai berikut :

1. Data primer berupa penelitian di lapangan.

Penelitian ini menggunakan Rancangan Acak Lengkap (RAL) 11 kali ulangan setiap perlakuan yang diteliti. Untuk mengetahui pengaruh perlakuan media tanam maka digunakan uji BNT pada taraf 5\%

2. Data Sekunder

Penelitian kepustakaan yaitu penelitian yang dilakukan dengan cara membaca dan mempelajari literatur-literatur yang berkaitan dengan masalah yang sedang diteliti.

\section{Prosedur Kerja}

Persiapan :

1. Tempat persemaian dibuat dengan luas $230 \mathrm{~cm} \times 115$ $\mathrm{cm}$, diatas permukaan tanah $30 \mathrm{~cm}$, jarak lantai dengan atap yaitu $120 \mathrm{~cm}$, sedangkan jarak tinggi naungan antara timur $130 \mathrm{~cm}$ dan barat $90 \mathrm{~cm}$, posisi persemaian menghadap pada sinar matahari pagi.

2. Bahan baku kompos adalah rumput dengan cara rumput dicacah atau dicincang sekitar $5 \mathrm{~cm}$, tujuannya agar rumput lebih cepat terdekomposisi.

3. Bahan aktif atau activator yang digunakan adalah EM4. Bahan ini tersedia di toko pertanian.

4. Bahan energi fermentasi untuk EM4 berasal dari gula, yaitu gula pasir yang akan digunakan sebagai energi pembiakan mikroorganisme yang terkandung dalam formula EM4.

\section{Pembuatan Kompos}

1. Larutan bahan fermentasi disiapkan dengan formulasi $10 \mathrm{ml}$ EM4 (1 tutup botol EM4) + $10 \mathrm{~g}$ gula pasir (1 sendok makan) +1 liter air tanah.

2. Bahan kompos berupa rumput dengan perlakuan sebagai berikut :

3. $100 \%$ rumput + larutan EM4, kemudian diaduk hingga merata.

4. Bahan kompos setelah dicampur kemudian disiram dengan larutan fermentasi hingga kadar air 30-40\%. Untuk mengetahui kadar air tersebut, setelah disiram dilakukan pengujian dengan mengepal bahan kompos. Kadar air telah cukup bila bahan kompos dikepal dengan tangan tidak mengeluarkan air dan bila kepalan tangan dibuka bahan kompos tetap menyatu atau tidak hancur.

5. Bahan kompos dimasukkan kedalam karung goni, diikat dan bagian bawahnya diberi lubang untuk mengalirkan air yang terbentuk selama proses pengomposan. Karung diletakkan diatas alas yang kering, diberi naungan untuk menghindari air hujan dan sinar matahari.

6. Selama proses pengomposan dilakukan pengamatan warna, bau dan tekstur kompos. Pengamatan ini dilakukan setiap hari pada pagi dan sore hari selama 14 hari.

7. Pengamatan berakhir apabila kompos telah matang. Kompos matang diketahui dari warna kompos hitam, bau seperti bau tanah, tekstur remah, temperature normal (sama dengan suhu ruangan) dan nilai $\mathrm{C} / \mathrm{N}$ ratio sekitar $20-30$.

8. Pengujian laboratorium dilakukan untuk menganalisa kandungan $\mathrm{C} / \mathrm{N}, \mathrm{pH}$, unsur hara makro dan mikro kompos.

\section{Persiapan Media Tanam}

1. Tanah yang digunakan dalam penelitian adalah tanah galian batu gunung, dengan perbandingan media tanah 3 bagian dan kompos 1 bagian, sedangkan sebagai pembanding adalah media tanah galian batu gunung 4 bagian. Untuk masing-masing perlakuan ini diulang sebanyak 11 kali ulangan.

2. Masing-masing tanah dibersihkan dari benda-benda seperti kerikil, batang dan sebagainya yang dapat mengganggu pertumbuhan, kemudian dikeringanginkan selanjutnya diayak dan dimasukkan 
kedalam polybag ukuran 15 x $23 \mathrm{~cm}$ sesuai dengan perlakuan.

3. Media tanam dilakukan analisa sebelum dilakukan penanaman, dan setelah penanaman juga akan dilakukan analisa.

4. Bibit tanaman kakao akan dipindah ke media tanam setelah bibit berumur 4 minggu (1 bulan).

\section{Perkecambahan Benih}

1. Benih kakao dikecambahkan pada tanah dengan menggunakan tempat bak semai, dengan cara benih kakao dimasukkan kedalam tanah hingga tertimbun tanah. Sebelum dikecambahkan benih terlebih dahulu direndam dengan fungisida.

2. Setelah berkecambah dan bibit telah berumur 4 minggu, kemudian bibit dipindah tanam ke polybag besar sesuai dengan perlakuan.

\section{Penanaman}

Masing-masing polybag akan ditanami 1 bibit tanaman kakao dengan pertumbuhan yang seragam pada masing-masing perlakuan.

\section{Pemeliharaan}

1. Penyiraman dilakukan 2 kali sehari yaitu pada pagi dan sore hari, disesuaikan dengan keadaan tanah. Jika tanah basah atau lembab maka penyiraman ditiadakan.

2. Penyiangan gulma dilakukan selama penelitian berlangsung, baik yang ada pada polybag atau tempat persemaian.

3. Pengendalian hama dan penyakit dilakukan apabila ada gejala serangan maka digunakan pestisida yaitu matador.

\section{E. Pengolahan Data}

Parameter tanaman yang diamati adalah :

1. Tinggi tanaman diamati 2 minggu sekali mulai pindah tanam sampai tanaman berumur 3 bulan. Dengan cara mengukur tinggi tanaman mulai dari dasar batang bawah sampai dengan ujung batang atas (pucuk), dikurangi $1 \mathrm{~cm}$.

2. Jumlah daun tanaman diamati setiap 2 minggu sekali mulai pindah tanam sampai tanaman berumur 3 bulan.

3. Diameter batang, diukur dengan menggunakan mikrokalifer. Dan dilakukan pengukuran 2 minggu sekali setelah pindah tanam sampai tanaman berumur 3 bulan..

4. Luas daun, diamati pada akhir pengamatan dengan cara mengambil semua daun pada tanaman kakao, kemudian diukur luasnya menggunakan leaf area meter.

Parameter media tanam yang diamati berdasarkan analisa media tanam awal sebelum tanam dan akhir setelah tanam, adapun unsur yang dianalisa adalah $\mathrm{pH}$, unsur hara makro (N, P, K, Ca, Mg, S) dan unsur hara mikro (Fe, $\mathrm{Zn}, \mathrm{Cu}, \mathrm{Mn}, \mathrm{B}, \mathrm{Mo}, \mathrm{Cl}$ ). Media tanam yang dianalisa meliputi tanah galian batu, kompos yang sudah matang, serta tanah galian batu yang sudah dicampur dengan kompos.

\section{HASIL DAN PEMBAHASAN}

\section{A. Hasil}

Analisis kompos : berdasarkan hasil analisis kimia di laboratorium terlihat bahwa kompos yang terbuat dari bahan rumput memiliki kandungan nilai $\mathrm{C} / \mathrm{N}$ yang baik yaitu 7,6. Dan kandungan unsur hara yang dimiliki lengkap baik unsure hara makro maupun mikro, serta $\mathrm{pH}$ kompos untuk $\mathrm{pH}\left(\mathrm{H} 2_{\mathrm{O}}\right)=6,86$ dan $\mathrm{pH}(\mathrm{KCL})=6,76$.

Analisis tanah : kandungan unsur hara tanah bekas galian batu meningkat dengan adanya perlakuan pemberian kompos dibandingkan yang tanpa perlakuan. Dapat terlihat pada tabel 1 di bawah ini.

Tabel 1. Hasil Analisis Tanah dan Kompos

\begin{tabular}{|c|c|c|c|c|}
\hline & $\begin{array}{l}\text { Kode } \\
\text { Sampel }\end{array}$ & $\begin{array}{l}\text { Kompos } \\
+ \text { tanah } \\
\text { Batu }\end{array}$ & Kompos & $\begin{array}{l}\text { Tanah } \\
\text { batu }\end{array}$ \\
\hline \multirow{4}{*}{$\begin{array}{l}\text { Kation } \\
\text { basa } \\
(\mathrm{me} / 100 \mathrm{~g})\end{array}$} & $\mathrm{Na}^{+}$ & 2,45 & 3,04 & 2,23 \\
\hline & $\mathrm{K}^{+}$ & 5,55 & 32,65 & 0,39 \\
\hline & $\mathrm{Mg}^{+2}$ & 4,53 & 8,04 & 3,47 \\
\hline & $\mathrm{Ca}^{+2}$ & 49,4 & 64,4 & 44,3 \\
\hline \multirow[t]{11}{*}{$\mathrm{pH}$} & $\mathrm{H}^{2} \mathrm{O}$ & 6,21 & 6,86 & 5,60 \\
\hline & $\mathrm{KCl}$ & 6,10 & 6,76 & 5,50 \\
\hline & P total (ppm) & 81,3 & 102,3 & 65,6 \\
\hline & $\begin{array}{ll}\mathrm{K} & \text { total } \\
(\mathrm{ppm})\end{array}$ & 125,3 & 203,6 & 98,2 \\
\hline & $\mathrm{C}$ total $(\%)$ & 3,42 & 12,65 & 1,95 \\
\hline & $\mathrm{N}$ total $(\%)$ & 35,3 & 96,2 & 28,7 \\
\hline & Rasio C/N & 10,3 & 7,6 & 14,7 \\
\hline & $\mathrm{Fe}(\mathrm{ppm})$ & $3.296,67$ & $2.763,33$ & $3.296,67$ \\
\hline & Mn (ppm) & 88,33 & 73,67 & 87,33 \\
\hline & $\mathrm{Zn}(\mathrm{ppm})$ & 36,33 & 25,12 & 10,67 \\
\hline & $\mathrm{Cu}(\mathrm{ppm})$ & 13,00 & 38,00 & 23,67 \\
\hline
\end{tabular}

Tinggi Tanaman $(\mathrm{cm})$ : berdasarkan hasil pengamatan sejak 2 minggu setelah tanam hingga 8 minggu setelah tanam, nampak bahwa rata-rata tinggi bibit kakao pada perlakuan tanah bekas tambang batu yang ditambahkan kompos berbeda nyata dengan bibit kakao pada perlakuan tanah bekas tambang batu tanpa penambahan kompos. Hal ini dapat dilihat pada tabel 2 berikut.

Tabel 2. Hasil pengamatan pengaruh pemberian kompos terhadap rata-rata tinggi bibit kakao

\begin{tabular}{|l|l|l|l|l|l|}
\hline No. & Perlakuan & \multicolumn{4}{|c|}{ Tinggi Tanaman (cm) } \\
\hline & & 2 MST & 4 MST & 6 MST & 8 MST \\
\hline 1. & K0 & $20,38^{\mathrm{b}}$ & $22,95^{\mathrm{b}}$ & $25,64^{\mathrm{b}}$ & $29,18^{\mathrm{b}}$ \\
\hline 2. & Kp & $24,45^{\mathrm{a}}$ & $27,55^{\mathrm{a}}$ & $31,36^{\mathrm{a}}$ & $35,64^{\mathrm{a}}$ \\
\hline
\end{tabular}

Keterangan : Angka rata-rata yang diikuti oleh huruf yang beda menunjukkan beda nyata pada uji BNT 5\% 
Jumlah daun (helai) : berdasarkan hasil pengamatan sejak 2 minggu setelah tanam hingga 8 minggu setelah tanam, nampak bahwa rata-rata jumlah daun bibit kakao pada perlakuan tanah bekas tambang batu yang ditambahkan kompos berbeda nyata dengan bibit kakao pada perlakuan tanah bekas tambang batu tanpa penambahan kompos. Hal ini dapat dilihat pada tabel 3 berikut.

Tabel 3. Hasil pengamatan pengaruh pemberian kompos terhadap rata-rata jumlah daun bibit kakao

\begin{tabular}{|l|l|l|l|l|l|}
\hline No. & Perlakuan & \multicolumn{5}{|l|}{ Jumlah Daun (helai) } \\
\hline & & 2 MST & 4 MST & 6 MST & 8 MST \\
\hline 1. & K0 & $5,64^{\mathrm{b}}$ & $7,00^{\mathrm{b}}$ & $8,00^{\mathrm{b}}$ & $9,82^{\mathrm{b}}$ \\
\hline 2. & Kp & $6,64^{\mathrm{a}}$ & $8,91^{\mathrm{a}}$ & $10,36^{\mathrm{a}}$ & $12,27^{\mathrm{a}}$ \\
\hline
\end{tabular}

Keterangan : angka rata-rata yang diikuti oleh huruf yang beda menunjukkan beda nyata pada BNT 5\%

Diameter Batang $(\mathrm{mm})$ : berdasarkan hasil pengamatan sejak 2 minggu setelah tanam hingga 8 minggu setelah tanam, nampak bahwa rata-rata diameter batang bibit kakao pada perlakuan tanah bekas tambang batu yang ditambahkan kompos berbeda nyata dengan bibit kakao pada perlakuan tanah bekas tambang batu tanpa penambahan kompos. Hal ini dapat dilihat pada tabel 4 berikut.

Tabel 4. Hasil pengamatan pengaruh pemberian kompos terhadap rata-rata diameter batang bibit kakao

\begin{tabular}{|l|l|l|l|l|l|}
\hline No. & Perlakuan & \multicolumn{4}{|c|}{ Diameter Batang (mm) } \\
\hline & & $2 \mathrm{MST}$ & 4 MST & 6 MST & 8 MST \\
\hline 1. & K0 & $1,92^{\mathrm{b}}$ & $2,52^{\mathrm{b}}$ & $2,98^{\mathrm{b}}$ & $3,30^{\mathrm{b}}$ \\
\hline 2. & Kp & $2,61^{\mathrm{a}}$ & $3,37^{\mathrm{a}}$ & $4,07^{\mathrm{a}}$ & $4,67^{\mathrm{a}}$ \\
\hline
\end{tabular}

Keterangan : angka rata-rata yang diikuti oleh huruf yang beda menunjukkan beda nyata pada BNT 5\%

Luas Daun $\left(\mathrm{cm}^{2}\right)$ : berdasarkan sidik ragam pengaruh pemberian kompos terhadap rata-rata luas daun bibit kakao pada akhir pengamatan menunjukkan beda nyata. Luas daun terbesar diperoleh pada perlakuan kompos (Kp) yaitu rata-rata $50,17 \mathrm{~cm}^{2}$ (tabel 5).

Tabel 5. Hasil pengamatan pengaruh pemberian kompos terhadap rata-rata luas daun bibit kakao

\begin{tabular}{|l|l|l|}
\hline No. & Perlakuan & Luas Daun $\left(\mathrm{cm}^{2}\right)$ \\
\hline 1. & K0 & $35,74^{\mathrm{b}}$ \\
\hline 2. & $\mathrm{Kp}$ & $50,17^{\mathrm{a}}$ \\
\hline
\end{tabular}

Keterangan : angka rata-rata yang diikuti oleh huruf yang beda menunjukkan beda nyata pada BNT 5\%

\section{B. Pembahasan}

\section{Analisis kimia kompos}

Menurut Simamora dan Salundik (2008), kompos dikatakan bagus dan siap diaplikasikan jika kematangannya sempurna. Kompos yang matang memiliki ciri fisik antara lain : tidak berbau busuk lagi, bentuk fisiknya menyerupai tanah yang berwarna kehitaman, strukturnya remah dan tidak menggumpal, serta suhunya mendekati suhu ruang.

Namun untuk kualitas kompos tidak dapat ditentukan hanya berdasarkan sifat fisik. Untuk kualitas kompos dapat diketahui berdasarkan hasil uji analisis kimia kompos di laboratorium.

Berdasarkan hasil uji analisis pupuk kompos terlihat bahwa kompos yang terbuat dari bahan rumput dengan penambahan activator EM4 menghasilkan pupuk kompos dengan kandungan $\mathrm{C} / \mathrm{N}$ kompos yang masih agak rendah yaitu 7,6. Padahal yang dikehendaki adalah rasio $\mathrm{C} / \mathrm{N}$ antara 10 - 20 berdasarkan SNI 19-7030-2004. Rasio C/N ini merupakan perbandingan dari unsur karbon (C) dengan nitrogen $(\mathrm{N})$ yang berkaitan dengan metabolisme mikroorganisme pengurai dalam proses pengomposan. Apabila rasio $\mathrm{C} / \mathrm{N}$ rendah maka nitrogen yang merupakan komponen penting pada kompos akan dibebaskan menjadi ammonia dan dapat menimbulkan bau busuk (Djuarnani, dkk, 2005).

Menurut Simamora dan Salundik (2008), pembuatan kompos dengan cara tradisional dapat memakan waktu berbulan-bulan. Namun dengan adanya activator maka dapat mempercepat proses pengomposan. Salah satu aktivator yang beredar di pasaran adalah EM4.

EM4 merupakan bahan yang mengandung beberapa mikroorganisme yang sangat bermanfaat dalam proses pengomposan. Mikroorganisme yang terdapat dalam EM4 terdiri dari Lumbricus (bakteri asam laktat) serta sedikit bakteri fotosintetik, actinomicetes, streptomicetes $S P$ dan ragi. EM4 dapat meningkatkan fermentasi limbah dan sampah organic, meningkatkan ketersediaan unsur hara untuk tanaman, serta menekan aktivitas serangga, hama dan mikroorganisme pathogen. EM4 sangat bermanfaat untuk menghilangkan bau pada limbah dan mempercepat pengolahan limbah (Djuarnani dkk., 2005).

Dengan adanya penambahan EM4 maka pembuatan kompos ini dapat berjalan lebih cepat dan mampu menghilangkan bau limbah, meskipun rasio $\mathrm{C} / \mathrm{N}$ masih dibawah standar. Meskipun rasio $\mathrm{C} / \mathrm{N}$ hasil kompos ini belum memenuhi standar yang ditetapkan SNI, namun kompos sudah dianggap matang karena sudah tidak berbau. Selain itu kompos juga sudah memenuhi syarat secara fisik lainnya, seperti warna yang kehitaman, struktur remah, dan sudah dingin (mendekati suhu ruang). Dengan demikian kompos dianggap masih layak untuk diaplikasikan.

Derajat keasaman $(\mathrm{pH})$ dalam tumpukan kompos berpengaruh terhadap aktivitas mikroorganisme pengurai. Kisaran $\mathrm{pH}$ yang optimum pada proses pengomposan aerob adalah 6,0-8,0. Jika nilai $\mathrm{pH}$ terlalu tinggi (basa) akan menyebabkan nitrogen dalam tumpukan kompos hilang akibat perubahan menjadi ammonia. Sedangkan apabila nilai $\mathrm{pH}$ terlalu rendah (asam) akan mengakibatkan sebagian mikroorganisme pengurai mati (Yuwono, 2006).

Menurut Simamora dan Salundik (2008), kompos yang sudah matang akan memiliki ciri tingkat kemasaman kompos agak asam sampai netral yaitu 6,5-7,5 Pada penelitian ini $\mathrm{pH}$ kompos adalah 6,68 untuk $\mathrm{pH}\left(\mathrm{H}_{2} \mathrm{O}\right)$ dan 6,75 untuk $\mathrm{pH}(\mathrm{KCl})$ (Tabel 1). Jadi kompos dianggap sudah matang dan memiliki $\mathrm{pH}$ yang sesuai.

Kandungan unsur hara makro dan mikro yang terdapat pada kompos yang dihasilkan dari penelitian ini memiliki kandungan unsur hara yang lengkap baik unsur hara 
makro maupun mikro (Tabel 1), hal ini disebabkan oleh kandungan bahan yang digunakan berasal dari bahan rumput dengan penambahan activator EM4. Menurut Rismunandar (2009), rumput sebagai pabrik zat karbohidrat, protein dan lemak yang terdapat dalam daun maupun cbang/rantingnya. Di mana rumput memiliki kandungan unsur air, zat-zat mineral yang tampak sebagai abu, protein, karbohidrat, lemak dan vitamin.

- Air terdiri atas zat hydrogen dan oksigen

- Abu terdiri atas zat oksigen, belerang, besi, fosfor, kalium, kapur, arang, magnesium, yodium, klor, dll.

- Protein terdiri atas karbon, hydrogen, oksigen, nitrogen, belerang, fosfor dan besi.

- Karbohidrat terdiri atas zat hydrogen, oksigen dan karbon.

- Lemak terdiri atas zat hydrogen, oksigen dan karbon.

Analisis kimia tanah bekas galian batu

Kandungan unsur hara tanah bekas galian batu meningkat setelah ditambahkan kompos (Tabel 1), hal ini terbukti bahwa kompos dapat meningkatkan kesuburan tanah bekas galian batu. Dari aplikasi pupuk kompos pada tanaman kakao terlihat bahwa semua parameter yang diamati baik parameter tinggi tanaman, jumlah daun, diameter batang umur 2, 4, 6, 8 minggu setelah pindah tanam serta luas daun pada saat akhir pengamatan, semua menunjukkan pengaruh yang berbeda sangat nyata antara yang diberi perlakuan pupuk kompos dan tidak. Hal ini terbukti bahwa kompos setelah diaplikasikan ke tanah bekas galian batu dapat menambah kandungan unsur hara baik unsur hara makro maupun mikro, mikroorganisme tanah pun akan kembali aktif sehingga kesuburan tanah bekas galian batu dapat diperbaiki (dapat meningkatkan kesuburan tanah bekas galian batu).

\section{Parameter Tanaman}

Berdasarkan hasil sidik ragam menunjukkan bahwa perlakuan kompos dari rumput menunjukkan hasil yang berbeda sangat nyata pada semua parameter baik parameter tinggi tanaman, jumlah daun, diameter batang pada umur 2, 4, 6, 8 minggu setelah pindah tanam dan luas daun pada akhir pengamatan dibandingkan dengan tanpa perlakuan. Hal ini disebabkan kompos yang diberikan pada tanah galian batu tersebut terbuat dari bahan rumput, dimana daun rumput adalah sebagai pabrik zat karbohidrat, protein dan lemak yang terdapat dalam daun maupun cabang/ranting melalui proses fotosintesis (proses asimilasi $\mathrm{CO}_{2}$ ) dan banyak mengandung unsur $\mathrm{N}$ dan zat karbohidrat. Dimana unsur $\mathrm{N}$ tersebut dipergunakan tanaman pada fase perkembangan vegetataif. (Rismunandar, 2009). Ditambahkan oleh Harjadi (2012), bahwa fase vegetatif terutama terjadi pada fase perkembangan akar, daun dan batang baru. Fase ini berhubungan dengan 3 proses penting yaitu pembelahan sel, perpanjangan sel dan tahap pertama dari diferensiasi sel.

- Pembelahan sel : terjadi dalam jaringan-jaringan meristematik pada tititk -titik umbuh batang dan ujung-ujung akar dan pada kambium.

- Perpanjangan sel : terjadi pada pembesaran sel-sel baru tersebut. Proses ini membutuhkan pemberian air yang banyak, adanya hormone tertentu yang memungkinkan dinding-dinding sel merentang dan adanya gula.

- Tahap pertama dari diferensiasi sel atau pembentukan jaringan, terjadi pada jaringan-jaringan primer.

Perkembangannya memerlukan karbohidrat seperti penebalan dinding dari sel-sel pelindung pada epidermis batang dan perkembangan pembuluh-pembuluh kayu baik di batang maupun di akar. Jadi kalau suatu tanaman membuat sel-sel baru, pemanjangan sel-sel tersebut dan penebalan jaringan-jaringan sebenarnya mengembangkan batang, daun dan system perakarannya. Kalau laju pembelahan sel dan perpanjangannya serta pembentukan jaringan berjalan cepat, pertumbuhan batang, daun dan akar juga akan berjalan cepat dan sebaliknya, sehingga dengan penambahan kompos yang terbuat dari bahan rumput yang banyak mengandung unsur $\mathrm{N}$ akan memacu pertumbuhan terutama pada fase vegetatif sehingga dapat terlihat pada parameter tanaman jelas menunjukkan hasil yang berbeda sangat nyata pada semua parameter baik pada tinggi tanaman, jumlah daun, diameter batang dan luas daun. Semua parameter ini terjadi pada fase vegetatif serta didukung oleh bahan kompos yang berasal dari rumput yang kaya akan zat $\mathrm{N}$ yang berfungsi sebagai zat pendorong pertumbuhan, menguatkan hijau daun, meningkatkan kadar protein. Di dalam tanah, zat $\mathrm{N}$ merupakan suatu zat yang meningkatkan pertumbuhan mikroorganisme yang penting bagi kesuburannya (Rismunandar, 2009).

\section{KESIMPULAN}

Rumput yang tadinya sebagai limbah dapat diolah menjadi pupuk kompos yang berkualitas dengan penambahan EM4. Kesuburan tanah galian batu dapat diperbaiki dengan penambahan pupuk kompos. Tanah galian batu dengan penambahan pupuk kompos dapat menumbuhkan tanaman kakao dan hasil pengamatan menunjukkan pengaruh yang berbeda sangat nyata pada semua parameter baik tinggi tanaman, jumlah daun, diameter batang umur 2, 4, 6, 8 minggu setelah pindah tanam dan luas daun pada saat akhir pengamatan.

Perlu menyebarluaskan ke masyarakat/pemerhati pertanian bahwa rumput dapat diolah menjadi kompos yang berkualitas dengan penambahan EM4 tanpa penambahan pupuk kandang.Perlu adanya penelitian lanjutan sampai pada fase generatif

\section{DAFTAR PUSTAKA}

Anonim. 2017. Komoditi Kakao. Dinas Perkebunan Kalimantan Timur. https://www.disbun.kaltimprov.go.id/artikel/kakao

Anonim. 2004. Analisis Dampak Lingkungan Penambangan Batu bara di Kecamatan Sangata, Bontang Utara, Bontang Selatan dan Muara Badak Kabupaten Kutai, Propinsi Kalimantan Timur. PT. Indominco Mandiri, Jakarta. 
Djuarnani, N., Kristian, dan Setiawan BS., 2005. Cara Cepat Membuat Kompos. PT. Agromedia Pustaka, Jakarta.

Hardjowigeno.S, 2010. Ilmu Tanah. PT. Mediyatama Sarana Perkasa. Jakarta.

Harjadi. S.S, 2012. Pengantar Agronomi. PT. Gramedia Pustaka Utama. Jakarta.

Kuswandi, 2012. Pengapuran Tanah Pertanian. Penerbit Kanisius, Yogyakarta..

Murbandono. HS, 2014. Membuat Kompos. Penebar Swadaya.Jakarta.

Rismunandar, 2009. Mendayagunakan Tanaman Rumput. Penerbit Sinar baru. Bandung.

Sanusi. B, 2004. Mengenal Hasil Tambang Indonesia. Penerbit PT. Bina Aksara. Jakarta.

Simamora, S. dan Salundik, 2008. Meningkatkan Kualitas Kompos. PT. AgroMedia Pustaka, Jakarta.

Siregar, dkk. 2009. Budidaya, Pengolahan dan Pemasaran Coklat. Penebar Swadaya, Jakarta.

Susanto, F.X. 2014. Tanaman kakao, budidaya dan Pengolahan Hasil. Penerbit Kanisius, Yogyakarta. 183 hal.

Sigit. P dan Marsono, 2005. Pupuk Akar Jenis Dan Aplikasi. Penebar Swadaya. Jakarta. 